\title{
Notes on some Contemporary Portuguese Amulets
}

\section{W. L. Hildburgh}

To cite this article: W. L. Hildburgh (1908) Notes on some Contemporary Portuguese Amulets, Folklore, 19:2, 213-224, DOI: 10.1080/0015587X.1908.9719825

To link to this article: http://dx.doi.org/10.1080/0015587X.1908.9719825

曲 Published online: 14 Feb 2012.

Submit your article to this journal $ऍ$

Џ Article views: 5

Q View related articles $₫$ 
sometimes eaten for the relief of disease, although I did not verify it, is likely to be true, since S. Gertrude is invoked especially for the relief of fevers, madness, and tumours, as well as against mice.

W. L. Hildburgh.

\section{Notes on some Contemporary Portuguese Amulets. ${ }^{1}$}

(Read at Meeting, isth April, 1908.)

THE material forming the basis of this paper was obtained at Lisbon and at Funchal during the spring of 1905 , and concerns, almost exclusively, amulets which are in common use and which may be procured at the shops, or from the sellers of cheap trinkets in the neighbourhood of the markets. A lack of sufficient knowledge of Portuguese necessitated the making of inquiries in a mixture of Spanish and Portuguese, or in English or French, so that I did not obtain that entire freedom of intercourse with the lower classes which would have been desirable. My notes can, therefore, make no pretence of including all the types of amulets used even in the two cities where they were secured.

the patroness of souls her symbol is a mouse." Baring-Gould, Curious Myths of the Middle Ages ("Bishop Hatto").

"Dans les images qu'on fait de Sainte Gertrude, des souris, des loirs, et des mulots courent autour d'elle et même grimpent sur sa crosse. En voici l'explication: Dans l'abbaye de Nivelles, on puisait de l'eau renfermé sous la crypte de l'église, et l'on s'en servait pour asperger les champs infestés par les campagnols et autres rongeurs ennemis de mecotlés . . . c'est surtout eu Belgique, parmi le peuple des campagnes, que sa culte est répandu : . . Le jour de sa fête, dans beaucoup de villages, on a la coutupqe d'offrir du blé, comme prémices de la moisson, afin de préserver celle-ci, par l'intercession de la Sainte, du fléau des nats." Notes communicated by a Belgian correspondent, and embodied in the account of $\mathrm{S}$. Gertrude in Les Petits Bollandistes, vol. iii. p. $48 \mathrm{I}$.

${ }^{2}$ Many Portuguese amulets not touched upon in this paper are briefly referred to by $\mathrm{J}$. Leite de Vasconcellos, in his excellent Sur les Amulettes Portugaises, published by the Societt de Geographie de Lisbonne, 1892, a twelve-page resume of a paper intended for presentation before the roth 
The greater part of my information was drawn from small shopkeepers, itinerant hawkers, and servants.

The amulets I saw for sale or in use in Madeira were practically identical with those of Lisbon, and appeared, for the most part, to be importations from Portugal. This fact is readily accounted for by the Portuguese character of the population, which is without an indigenous element, for the group of islands were, it is said, entirely uninhabited at the time of their discovery by the Portuguese. Although in Lisbon amulets are still very commonly used, at Funchal comparatively few are to be seen, and these are said (and justly, so far as my observation could confirm the statement) to be disappearing with a noticeable rapidity, a marked decrease of belief in the virtues of the majority of them having occurred even within the five years which had just passed. The so-called "Zodiac-rings," of gold or silver, to be found in many of the shops at Funchal, are merely copies, made there for sale to the numerous visitors, of the gold rings ornamented with the signs of the Zodiac which are made by the natives of the West Coast of Africa. There is, so far as could be determined, no amuletic virtue attributed to such rings by the people of Madeira.

The "evil eye," mau olhado, is generally believed in, and the amulets against it are very common. Of these, horns of various kinds and representations of a human hand making the "fig"

Session (which did not take place as expected) of the Iniernational Congress of Orientalists, which treats principally of amulets in their general aspects.

Other papers, by the same writer, on the subject of amulets are :-

Amuletos populares portugueses, " from the Revista da Sociedade de Instruccão do Porto, Porto, 1882.

Amuletos italianos e portugueses," in the Reviste Scientifica, Porto, 1882.

Moedas Amuletos," in Elencho das licốs de numismatica, rol. i., p. 21, 1889.

Amuletos, in $O$ Archeologo Portuguts, vol. v., Lisbon, 1905.

Signification religieuse, en Lusitanie, de quelques monnaics perede d'un trou, in $O$ Archeologo Portugu's, Lisbon, 1905.

Religoes de Lusitania, vol. i., contains several references to amulets.

There is also a portion of Concelho de Elvas, " (of Victorino d'Almeda), vol. i., pp. 495 et seq., by A. Thomás Pires, devoted to "Amuletos."

I have not been able to obtain for consultation copies of the papers marked (*). 
离

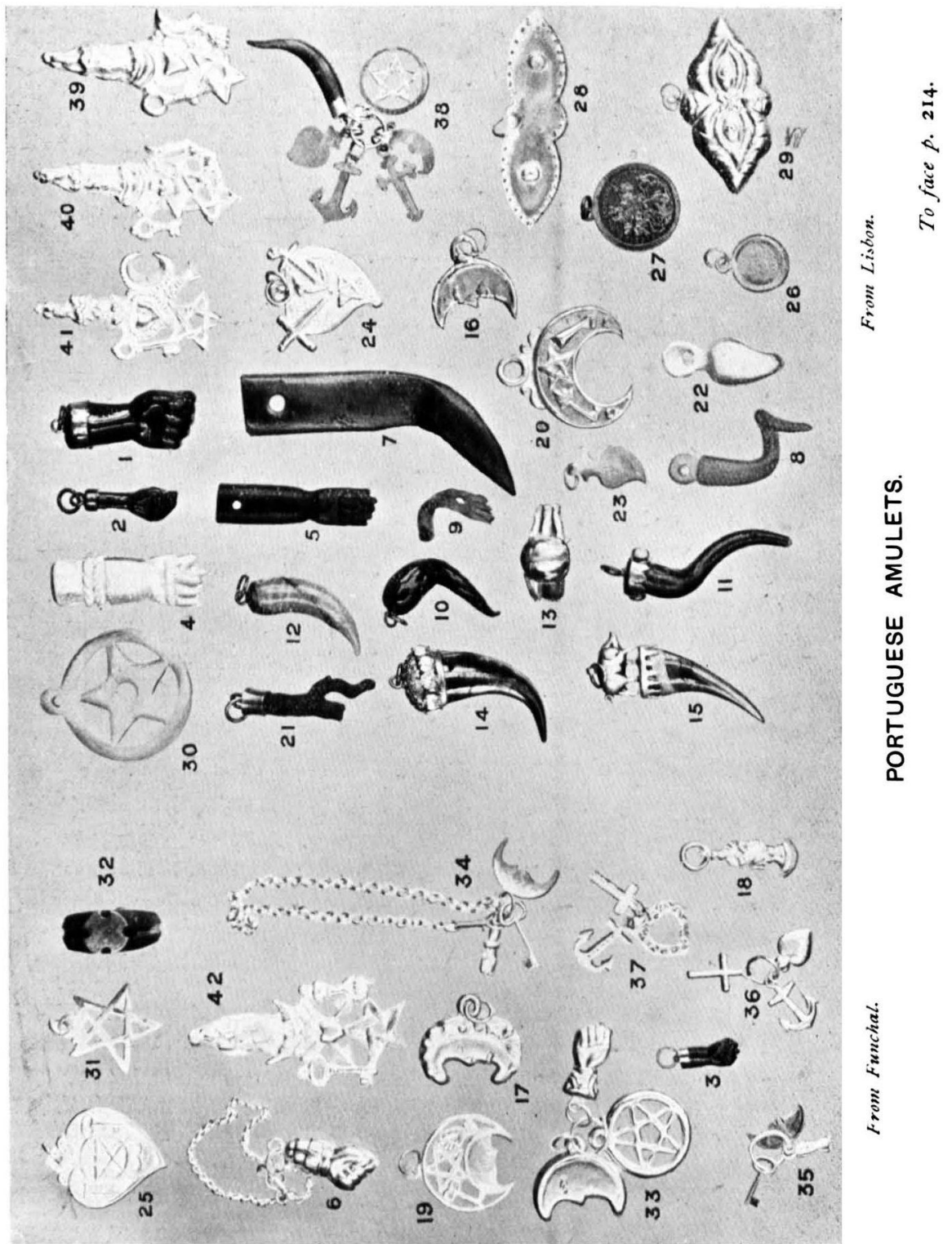


gesture, with the thumb protruding from between the index and middle fingers of a closed fist, are the most frequent. ${ }^{2}$ Very many of both of these charms appear to be imported from other European countries, but there are also many which are of native manufacture, some of the latter being exceedingly primitive in construction and correspondingly low in price.

This hand, an extremely ancient amulet, the mano fica of Italy, is commonly called a figa at Lisbon. In its simple form it is most often made of a black or red composition, with a metal termination to which a ring for suspension is attached (Figs. I, 2, 3); or of bone with a small hole through the wrist (Fig. 4). Black as a favourite colour for the hand may be a reminiscence of jet, formerly a favourite material in Spain for the fabrication of this amulet; and red may be attributed to the widespread belief, of which other Portuguese examples were noted, in the protective virtues of that colour or of coral. I did not note artificially coloured hands of any other hues. Hands made of horn (Fig. 5), of silver (Fig. 6), or of gold, are to be found, but less often than those of bone or composition. Some of the hands are so rude in design as to be recognizable as such only by the initiated, perhaps the limit of this symbolism being reached in certain amulets whose straight-cut ends are divided by four small notches, forming five divisions which represent the knuckles of the fingers and the tip of the thumb (Fig. 7).

The figa occurs in a number of compound amulets, notably in the elaborate cinco seimao; the hand, whilst almost always present in such amulets, may, however, occasionally appear in a different form.

Small images of horns are very common, for a horn, by virtue of its shape as well as by that of its substance, is regarded as an excellent preservative against the effect of the evil eye. ${ }^{2}$ Such images are sometimes mere twisted fragments of cow's-horn, (Fig. 8), the upper and perforated end perhaps notched to indicate a figa (Fig. 9); sometimes pieces more carefully shaped,

${ }^{2}$ Cf. "Notes on Spanish Amulets," Folk-Lore, vol. xvii., pp. 458-460, and Pl. V.

"Cf. "Notes on Spanish Amulets," pp. 455-457, and PL IV. 
and set in metal sockets with a suspending ring; sometimes more or less perfect representations in glass, or some other composition, which are usually coloured black or red (Figs. 10, 11, 12). A silver finger-ring with a hemispherical bezel upon which are engraved religious symbols, (a cross between two flaming hearts) and having a minute piece of horn set within in such manner as to touch the skin, is often to be met with (Fig. 13). In this amulet the horn, although considered to be efficacious against fascination, is used especially as preventive of, and as a renedy for, nervous complaints, particularly those affecting the head.

Stag's horn seems now to be seldom employed against the effects of the evil eye. In Madeira I was told that it had formerly been greatly esteemed for its protective virtues in that connection, though now but little used; at Lisbon I noted none exposed for sale, though it was occasionally to be seen upon donkeys, by whom it is worn sometimes on the forehead, sometimes at the neck. Although comparatively few of these animals had any amulets in sight, one of them, apparently owned by a peasant, carried a very elaborate set of amulets against the evil eye (PI. IV). It consisted of : $a$, the tip of a stag's horn, perforated for suspension, and with two additional holes through which bunches of ribbons of several colours were passed, having attached to it a circular brass plate with eight radial perforations which was carried upon the donkey's forehead; $b$, a piece of black horn, perforated for suspension, and with a second perforation through which a bunch of coloured ribbons was passed, which was hung below the throat; $c$, a very feeble brass bell, suspended with the black horn; and $d$, two bits of red ribbon which were tied, one at each flank, to the harness over the haunches. There can be little doubt that each of these objects, with the exception of the probably merely ornamental brass plate, was intended as a protection. The multi-coloured bunches of bright ribbons were supposed to serve, as in many other countries, to attract the evil eye to themselves, and to divert its effect from the animal wearing them. The red ribbons were, it may be presumed, protective by virtue of their colour, for bits of red cloth or ribbon are not infrequently to be seen tied to the harness, 
葛

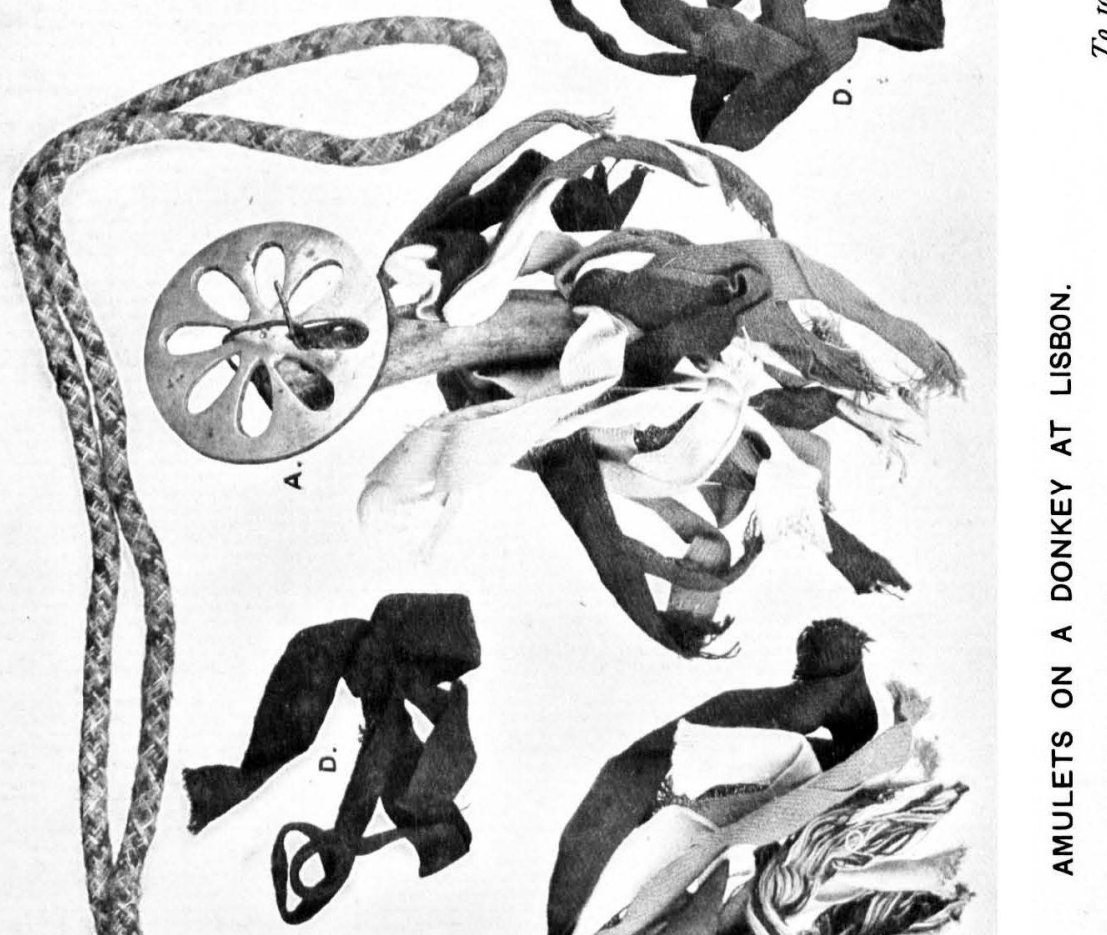




\section{Collectanea.}

generally between the donkey's eyes. The almost inaudible bell, however, may have been, instead of actually amuletic, only the survival of an amuletic custom, since inquiries made as to the purposes of certain very small, and similarly feeble, bells fastened to the harnesses of horses above the head, brought forth no useful information.?

Copies of claws, made of glass and mounted in metal sockets, are worn against the effect of the evil eye. One such is black, with its brass socket set with bright bits of glass (Fig. 14); another is multi-coloured, like the bunches of ribbons, and has a small metal pig, said to be for the purpose of attracting good luck, attached to its socket (Fig. 15).

Lunar crescents, usually, though not always, of silver, and human-faced, are common in Portugal. They occur singly (Figs. 16, 17), in sets of amulets (Figs. 34, 35, 38), and in compound amulets like the cinco seimato (Figs. 39-42). The individual crescents are worn by babies, principally to protect them from the supposed pernicious effect of the moon, which, it was said, causes an illness, luada, of the nature of stomach trouble or colic. The crescent in this form is, of course a profane amulet; it is sometimes, though rarely, changed into one to which no exception can be taken from a religious point of view, by the addition of an image of the Virgin-who is almost invariably shown, in Portuguese representations of all kinds, standing upon an upward-curving crescent moon (Fig. 18). There is a compound amulet whose basis is a crescent, the interior curve of which is formed by a smaller, and human-faced, crescent, whilst the remainder of the space is occupied by a figa, a key, and a pentangle (Fig. 19); in another form of the same amulet the crescent moon within the curve is lacking (Fig. 20). The lunar crescent appears upon almost all of the compound amulets, and in almost every set.

Small branches of red coral (Fig. 2I) are worn against fascination, and also, so it was said, against troubles affecting

${ }^{1}$ Dr. Leite de Vasconcellos has informed me, since the above was written, that the little bells borne by animals are sometimes ornamented with a cross, to enhance their virtue ; also that the small bells are employed as a protection against lightning (see Tradicöss populares, p. 64). 
the head. The coral, if genuine, is supposed to break when exposed to the influence of the evil eye.

A representation of $a \cdot k e y$ in silver, which is a frequent amulet, I did not find employed by itself; it seemed to occur invariably either as one of the charms of a set, or, with other symbols, in some compound amulet. At Lisbon it was found upon the cinco scimato, and upon one lunar crescent alone (Figs. 39, 40, 41, 20), but at Funchal it appeared not only upon several compound amulets (Figs. 19, 25, 42) but, with a silver lunar crescent and a silver figa, it made up a favourite set of charms for the protection of infants (Figs. 34, 35). On the Lisbon crescent (Fig. 20) the usual form of its handle is replaced by what seems to represent a flame. The key was said to be a "man" (male) key, and commonly worn by young children, but its special preservative attributes could not be ascertained; the phallic significance was, in some charms (Figs. 19, 25), quite clearly indicated by the shape of its handle. In Italy small silver keys, called "Keys of the Holy Spirit," which have been blessed by a priest, are worn by infants for preservation from convulsions and similar disorders. ${ }^{1}$ In Italy, also, the key is employed as a phallic symbol, and is supposed to have, amongst other virtues, that of, in certain circumstances, bringing good-luck to the wearer. ${ }^{2}$

The heart, in its conventionalized form, has an extended use in Portugal as an amulet against the evil eye. ${ }^{8}$ It appears, as in other Roman Catholic countries, in the combination of a heart, a cross, and an anchor, the emblems of charity, faith, and hope, to which a protective virtue is assigned because of the religious conceptions associated with them (Figs. 36, 37). But it appears alone as well, and also with profane amuletic symbols in sets (Fig. 38), or as the basis of (Figs. 24, 25), or

${ }^{1}$ Bellucci, Catalogo Descrittivo Amtuleti Italiani, Perugia, 1898, Tablet XV.

'Leland, Etruscan Roman Remains, Lond., 1892, p. 364. Also Payne Knight, Symb. Lang.

In a note to me Dr. Leite de Vasconcello makes the following comment on this statement: "I believe that the beart, as an amulet, is, on the contrary, dead in Portugal. It is worn, . . . but without any great preservative signification being attached to it by the people." 
upon (Figs. 39, 40, 4I, 42), compound amulets. At Lisbon a small heart of bone, intended for suspension (Fig. 22), was obtained, and a little silver heart (Fig. 23) having an arrow rudely engraved upon each face, both of which pendants were said to be useful in counteracting the effects of the evil eye. Upon a larger silver heart, also from Lisbon, there are a cross, an anchor, and a pentangle (Fig. 24); and upon a similar one from Madeira are a pentangle within a circle, an open hand with the palm showing, a lunar crescent, and a key of phallic type (Fig. 25).

A small crucifix or cross, worn as elsewhere as a general protection, is considered to be a preservative from fascination. There is a small silver coin (Fig. 26), upon the face of which is represented an armillary sphere, ${ }^{1}$ and upon whose reverse are five equal-armed crosses, four small ones about a larger one, which is to be seen at many of the silversmiths' shops in Lisbon. ${ }^{2}$ This coin, prepared for suspension, is much worn by children, and though reported by one of the silversmiths selling it to be without supposed amuletic virtues, serves nevertheless, according to a woman informant, to avert the effect of the evil eye or some similar misfortune or malady.

Other simple amulets having religious associations are the medal of St. George (Fig. 27), "Equitum Patronus," with "In Tempestate Securitas" and a ship upon its reverse, whose specific intention in Portugal I could not determine; and small pairs of conventionalized eyes, stamped from thin silver sheets, and having a suspending ring (Figs. 28, 29). These latter, which are very like ex votos in design, are much smaller than the generality of such offerings, and were meant, I was told, to

${ }^{1}$ Leite de Vasconcellos, in $O$ Archeologo Portuguts, vol. x., p. 171, June, 1905.' "The people of Portugal call still, though very improperly, sino saimão the armillary sphere which appeared during the eighteenth and nineteenth centuries on the reverse of our coins; for this reason they employ them as amulets."

${ }^{2}$ [This device, heraldically known as "a cross potent between four crosslets," was the shield of the Crusader Kings of Jerusalem. Tinctured or upon a field argent, it was the sole permitted instance of "metal upon metal." Differently tinctured, it forms the coat of the Episcopal See of Lichfield. ED.] 
be worn by children to put them under the protection of St. Lucy, the patroness of eyesight. That they are not intended solely, if at all, for offerings seems to be indicated by their exposure in numbers, for sale at shops where few or no votive offerings, but many amulets, were shown. ${ }^{1}$ Other eye-forms used in Italy against the evil eye, I did not see in Portugal.

A very favourite amulet against fascination, and one which appears to survive most actively in Portugal amongst the Christian nations, is the pentangle, the proper sino saimao or "Seal of Solomon," sometimes, because of the number of its points, called the cinco saimito (or seimado). This, as all know, is a five-pointed star, whose outlines are formed by five straight lines passing directly from tip to tip, so that it is composed of a pentagon upon each of whose sides a triangle is erected (Figs. 30,31 ). It is a very ancient magical symbol of Oriental origin, which was greatly employed by the mediaeval astrologers and magicians throughout Europe. Its existence in Portugal, after the practical extinction of its amuletic significance elsewhere in Europe, may be due to the Moorish and Jewish influences which were greater in the Peninsula than in the rest of Europe. ${ }^{2}$ It is curious that, so far as I was able to discover, no trace of this symbol as a contemporary, or even recent, amulet exists in Spain.

The "Seal of Solomon," though occasionally wom by itself, appears much more frequently in sets of charms, or upon compound amulets, of both of which it usually forms a part. It is most frequently made of silver, sometimes of bone. Very often the figure is drawn with its lines symmetrically interwoven, so that each line passes over the first, and under the second, of the two lines which it crosses.

Bone, as indicated by several of the foregoing descriptions, is a material commonly used for the fabrication of amulets (Figs. $4,22,30$ ), and especially for that of the figa. It is probable

${ }^{1}$ Dr. Leite de Vasconcellos considers these to be ex votos merely.

'In Sur les Amulettes Portugaises Dr. Leite de Vasconcellos gives several examples illustrating the great prevalence of this symbol for protective purposes. ITe speaks, also, of its Semitic origin, and suggests that it has, in a number of instances, supplanted and replaced the swastika. 
that, although no such virtue was mentioned in connection with it, it has, as elsewhere on the Continent, a preservative virtue attributed to it, which, added to its durability and cheapness, makes it a favourite for the purpose.

A belief related to that in fascination, prevalent in Portugal, and still to be found in Spain, is that paralysis and a condition in which the limbs and features are permanently contorted are produced by "bad currents of air"-that is, by invisible evilworking currents in the atmosphere-striking upon the person. To guard against these currents a steel finger-ring, lined with silver and with a gold or gilt bezel (Fig. $3^{2}$ ) is worn. It is the steel alone in this ring which is said to have the power of diverting the evil, the silver serving merely to protect the finger from rust, and the gold as ornamentation. "Electric" fingerrings of the usual type, having alternating strips of copper and zinc within a gold or gilded casing, and imported from other Continental countries, are worn as a cure for nervous diseases. Amongst the Portuguese, as amongst other peoples, there is a tendency to attempt to make the more certain of a desired result by accumulating various amulets intended each individually to secure that result. This has brought about in Portugal not merely the formation of sets of individual charms, but the construction of various very elaborate compound amulets as well. Both in the sets and in the compound amulets a strange and interesting intermingling of sacred and profane symbols may be observed, an intermingling which appears to be considerably more frequent than in Italy, and, at the same time, less marked by a consciousness of the incongruity of the proceeding.

The sets of amulets consist generally of three or six separate charms, mostly of silver and very small, fastened to a single small ring by which they are attached to the person. For infants, such sets may be put upon a slender chain encircling the wrist, and may be formed, as often at Lisbon, of a crescent moon, a figa, and a pentacle (Fig. 33), or, as at Funchal, of the two former objects, with, frequently, a key in the place of the pentangle (Figs. 34, 35). Another set commonly worn in the same manner is made up of the cross, the 
heart, and the anchor (Figs. 36, 37). Of the larger sets a typical and not unusual example is one composed of the cross, the heart, the anchor, the lunar crescent, and the pentangle, all made of silver, and a horn made of horn (Fig. $3^{8}$ ).

The most interesting of the compound amulets is the cinco seimao (as it is sometimes called) or sino saimao (properly only the pentagram) (Figs. 39, 40, 4I, 42), one of the most elaborate single amulets, I believe, of a standard type, in existence, and one which exhibits, in various ways, a remarkable resemblance to the Neapolitan "cimaruta." The cinco seimaa is always of silver, and usually of rude workmanship, most often being cast, with perhaps a little subsequent finishing on the face, or made in an equally negligent manner, from a sheet of metal. It is formed of five symbols-a pentagram, a fga, a human.faced crescent, and a key, grouped about a heart pierced by two arrows-which are surmounted by a figure of the Virgin ("Our Lady"), and has at the back a ring for its attachment. Each of these symbols is, as has been shown, individually and secularly amuletic, whilst a religious character is given to the complete charm by the arrows crossing within the heart (making it a "Sacred Heart"), and the image of the Virgin.

The human-faced lunar crescent, always present in this amulet, although generally distinct from the crescent upon which the Virgin stands, sometimes replaces it. It is not unlikely that the arrows, which are in some forms strongly marked, have, as elsewhere in ancient and modern Europe, a symbolic, and probably protective, meaning of their own; and they are arranged so as to form a cross, although their junction is unseen.

Upon certain specimens of this amulet (Fig. 4I) there is a very small emblem whose symbolic meaning in Portugal I was not able to determine. It is placed just above the wrist of the figa, and next to the human-faced crescent, and it resembles a four-petalled flower, having four leaves surrounding a common centre. That it is amuletic, and that it has some intimate connection with the crescent and the hand, may be inferred from its position, and from the fact that there is a type of 
Spanish amulet, seemingly no longer used, of silver, composed of a crescent within whose body this emblem is placed, and from the centre of whose inner curve a figa projects. ${ }^{1}$ Whilst there is a strong possibility that it represents the rue (or some other) flower, forming an additional point of resemblance between the cinco seimão and the cimaruta, it may perhaps be ascribed to a Mohammedan influence, since it is used in Algeria, with or without the crescent, as a decoration for amulet pouches. Just such an emblem, a centre with four spokes or petals, is used in Moorish decoration as a repre. sentation of the strongly-protective number five. ${ }^{2}$

In the cinco seimato we find combined the protective virtues of silver, of an image of the Virgin, of the lunar crescent, the key, the ithiphallic hand, the heart, and the pentagram, and possibly also those of the flower-like emblem, the arrow, and the cross. In the Neapolitan cimaruta we find embodied several of the same conceptions which are embraced by the cinco seimão. The cimaruta, literally the "sprig of rue," is a stem from which extend short branches, each of which holds an amuletic emblem or symbol at its extremity. It is worn as a protection against "jettatura" (the evil eye), it is almost always of silver, and usually roughly made, and it counts amongst its symbols the lunar crescent, the key, the ithiphallic hand (the "mano fica"), a flower-like emblem, and often the heart and the arrow. The number of coincidences between the two amulets appears too great to be the result of mere chance; in fact it is so great that we may fairly assume that the amulets themselves have had a common origin, and that one or the other has changed in form, and in some of its less valued symbols, during the centuries since their genesis.

There are several similar but less common compound amulets,

1 "Notes on Spanish Amulets," pp. 457, 458, and PI. VII. Since writing these notes I have seen a "fig" hand of crystal whose metal socket for suspension was ornamented with this emblem round the wrist.

'Westermarck, The Magic Origin of Moorish Designs, J.A.l., vol. xxxiv.

'Elworthy, Evil Eye, pp. 343 et seq. and 355 ; and Gunther, Folk-Lore, June, I905.

¿Specimens made of base yellow metal, although rare, sometimes occur. 
described in the notes on the heart and the lunar crescent, which, however, hardly appear to be standard types. They also are of silver, but they do not include so many symbols as the Virgin-surmounted charm, five symbols appearing in one of them (Fig. 25), and four in each of the three others (Figs. 19, 20, 24). It is curious that in two of these latter (Figs. 19, 20) the symbols are all profane, the heart, to which a religious conception is sometimes attached, being lacking; and that in the other (Fig. 24) the symbols are sacred in character, with the exception of the pentangle. It is interesting to note that neither in any of the compound amulets mentioned, nor in the cimaruta, does a representation of a horn, otherwise a favourite protection, occur.

The only Spanish amulets which I have found which resemble the Portuguese compound amulets are the combined crescent, figa, and four-petalled flower, which may be related to the cinco seimao; and the elaborate jet ithiphallic hands upon which appear a lunar crescent, or, more seldom, a lunar crescent and a heast. ${ }^{1}$

W. L. HILDBURGH.

Folk-Tales of the Aborigines of New South Wales.

THe following stories have been obtained by me personally from old natives whom $I$ have been acquainted with in different parts of New South Wales. In 1899 I published seven aboriginal stories, ${ }^{2}$ and in 1904 a number of myths and traditions current among the natives of New South Wales and Victoria. ${ }^{8}$ I have a considerable number of all sorts of legends still in MS., awaiting publication. R. H. MATHEWS.

I. Why Fishes inhaeit the Water. (Kamilaroi Tribe.)

In olden times there were some people who had the form of different kinds of fish, but they always roamed about and hunted 1"Notes on Spanish Amulets," p. 457, and Pl. VII., and pp. 459, 460, nd Pl. V.

2 Folklore of the Australian Aborigines (Sydney, 1899), pp. 1-35.

Journ. Roy. Soc. N.S.IV., xxxvii. Pp. 278-286 and 337-376. 